\title{
A note on modification of pancreatic juice and bile collection method in sheep
}

\author{
J. Rawa, W. Korczyński', J.J. Pająk, J. Skomial, J. Rutkowski, \\ B. Kowalik and Z. Długołęcka
}

The Kielanowski Institute of Animal Physiology and Nutrition, Polish Academy of Sciences 05-110 Jabłonna, Poland

(Received 28 July 2008; accepted 27 October 2008)

\begin{abstract}
The aim of the study was to modify and evaluate the method of management of pancreatic juice and bile secretions in sheep in chronic experiment. Experiment was performed on 12 adult male Corriedale sheep of $54 \pm 2.4 \mathrm{~kg}$ body weight, fitted with two biomedical silicone catheters in the common bile duct according to the method described by Kato and Young (Kato et al., 1999) and our modification duodenal cannula. Duodenal cannula was equipped with silicone valve in the basement part to prevent secretions backflow.

Except the collection time, animals were freely moving in the individual pens and all secretions were returned to duodenum by means of constructed device. During all experimental treatments secretion volume of pancreatic juice was from 11.7 to $34.8 \mathrm{ml} \cdot \mathrm{h}^{-1}$.

Modification of Kato and Young method allows extending the period of animals use even up to more than 6 months. Moreover, it positively impacts animals welfare by reducing time spending in the metabolic cages, and saves labour expenses.
\end{abstract}

KEY WORDS: sheep, pancreatic juice, bile, collection method

\section{INTRODUCTION}

Animals Welfare Committee is recently focused on un-stressed experimental conditions. On the other hand the costs of experiments and labour constantly increase. The aim of the study was to modify and evaluate the method of management of pancreatic juice and bile secretions in sheep in chronic experiment. The main scope of the study was to investigate the effect of natural, or protected

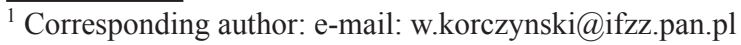


from rumen degradation, plants oils together with two proteins sources different in rumen dissaperance on exocrine pancreatic secretion in sheep.

Except the collection time, animals were freely moving in the individual pens and all secretions were returned to duodenum by means of constructed device. It allows a quantitative analysis of pancreatic and bile secretion independently from planned sampling schedule.

\section{MATERIAL AND METHODS}

\section{Surgery}

Before surgery sheep were starved for $48 \mathrm{~h}$ with free access to water. Animals were sedated with atropine (Atropinum sulfuricum, Biowet Poland $-0.1 \mathrm{mg} \cdot \mathrm{kg}^{-1}$ body weight (BW) $s c$ ) and ketamine (Ketonal-Polfa Drwalewo - $10 \mathrm{mg} \cdot \mathrm{kg}^{-1}$ BW iv). Anaesthesia was initiated with $4 \%$ halothane (Narcotan, Leciva, Czech Republic), nitrous oxide and oxygen (1 and $1.5 \mathrm{dm}^{3} \cdot \mathrm{min}^{-1}$, respectively), then animals were intubated with endotracheal tubes and anaesthesia was sustained with $1.5-2 \%$ halothane during entire surgery. After the right flank paracostal laparotomy, the common bile duct was identified close to its opening to duodenum; next two medical grade silicone catheters (35 $\mathrm{cm}$ in length, $2 / 4 \mathrm{~mm}$ I.O/O.D.) were inserted.

Pancreatic catheter was placed close to duodenum while bile catheter was implanted below the pancreatic duct entry to the common bile duct. Both catheters were constructed to prevent pulling out by means of $2 \mathrm{~cm}$ diameter biomedical silicone stopper rings placed about 10 and $16 \mathrm{~cm}$ from the tip of pancreatic and bile catheter, respectively. Next, biomedical silicone duodenal cannula $(4 / 6 \mathrm{~mm}$ I.O/O.D., round 2-2.5 $\mathrm{cm}$ shaped base with valve) was implanted (Figure 1).
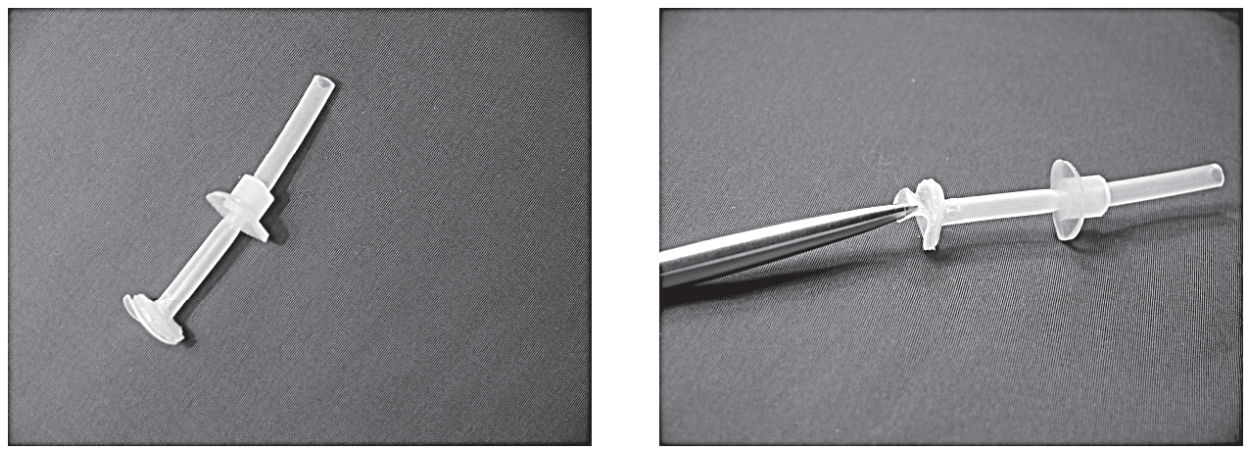

Figure 1. Duodenal cannula. Silicone valve in cannula base 
Abdominal cavity was flushed with 21 of warm, sterile saline; next the catheters were exteriorized vertically and abdominal wall was close in conventional 4 layers surgical sutures.

After surgery animals received analgesic agent Metamizolum natricum (Biovetalgin, Biowet, Drawlier, Poland, $20 \mathrm{mg} \cdot \mathrm{kg}^{-1} \mathrm{BW}$, im) during 3 consecutive days and antibiotic - amoxicillin (Clamoxyl, GlaxoSmithKline, Poland, $15 \mathrm{mg} \cdot \mathrm{kg}^{-1}$ BW, twice every two days, $s c$ ).

During first day after surgery, duodenal cannula was closed while both catheters remained open to allow not restraint secretion flow and implantation sites healing. During 7-10 days of recovery period animals were kept in individual pens equipped with the collection bottle (Figure 2).

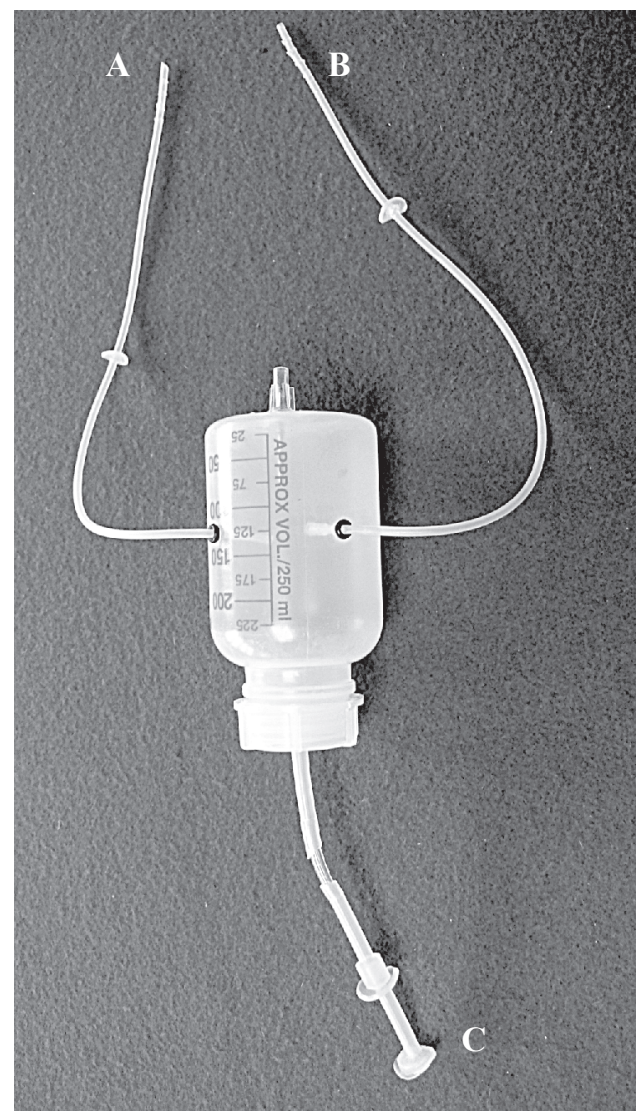

A - pancreatic catheter

B - bile catheter

C - duodenal cannula

Figure 2. Bottle for collection and returning pancreatic juice and bile 


\section{Equipment}

Originally, Kato and Young (Kato et al., 1999) method requires non-stop returning pancreatic juice and bile to the duodenum via duodenal catheter not cannula by peristaltic pumps. During recovery and in between trials sheep were equipped with specially designed set for collecting and returning mixed secretions to the duodenum. Set was built of $250 \mathrm{ml}$ plastic autoclavable bottle (Kautex Textron $\mathrm{GmbH}$ and Co. KG, Germany) with a venflon-valve protected from under pressure in the bottom of bottle, two holes for catheter placement and one hole for duodenal outflow in the screw with silicone tubing attached to connect to duodenal cannula (Figure 2).

The up side down positioned bottle was attached on the right side of the animals by means of bottle holder and belly strap. Duodenal cannula was equipped with silicone valve in the basement part to prevent secretions backflow (Figure 1).

\section{Animals}

Experiment was performed on 12 adult male Corriedale sheep (signed with letters) of $54 \pm 2.4 \mathrm{~kg} \mathrm{BW}$, fitted with two biomedical silicone catheters in the common bile duct according to the method of Kato and Young (Kato et al., 1999) and our modification duodenal cannula.

All experimental procedures were accepted by Local Animal Welfare Committee. Animals were fed twice a day at 8 a.m. and 4 p.m. with two isoprotein diets $(17 \%$ crude protein in dry matter (DM)) different in the high or low rate of rumen disappearance - casein and maize zein, respectively. Other diets components and nutrients sources were: meadow hay, potato starch, vitamins and mineral supplement. The diets were enriched with sunflower, linseeds or rapeseeds natural oils (5\% in DM), its protected forms (calcium salt of linseeds and sunflower oil of fatty acids) or dehulled sunflower seeds. The control diet without oil supplementation was below energetic requirements.

During the 3 day trials animals were kept in the metabolic cages and the pancreatic juice and bile were collected and returned by peristaltic pomp into the duodenum via the modified cannula (Figure 1) accordingly to secretion rate.

Sampling of pancreatic juice and bile were performed every hour between 8 a.m. - 4 p.m. Pancreatic juice and bile were collected to the containers kept in crashed ice; after withdrawing $5 \% \mathrm{w} / \mathrm{w}$ of pancreatic juice for further analysis the remain part was immediately mixed with bile and returned to the duodenum.

Animals were disconnected from peristaltic pumps during the nights between planned trials and moved to individual pens during 10 days adaptation period to the new experimental diets. 


\section{Statistical analysis}

Data are presented as mean \pm standard error of the mean (SEM). Statgraphics Plus ver. 7.0 for was used to assess the regression analysis. Presented data were pooled from the number of dietary treatments for each animal to present the advantages of the modified method. The differences between the treatments and diets are the scope of the different publication.

\section{RESULTS AND DISCUSSION}

Modification of the method allows extending the period of animals use even up to more then 6 months (Table 1). Any significant variation in secretion volume of pancreatic juice or bile at the same animals was not achieved. Volume of pancreatic juice was from 11.7 to $34.8 \mathrm{ml} \cdot \mathrm{h}^{-1}$ in sheep $\mathrm{H}$ and $\mathrm{L}$, respectively.

Table 1. Mean volume of pancreatic juice, bile and protein output in sheep in relation to time (days) after surgery

\begin{tabular}{|c|c|c|c|c|}
\hline \multirow{2}{*}{ Sheep } & \multirow{2}{*}{ Days } & \multicolumn{2}{|c|}{ Secretion, $\mathrm{ml} \cdot \mathrm{h}^{-1}$} & \multirow{2}{*}{$\begin{array}{c}\text { Protein secretion, } \\
\mathrm{mg} \cdot \mathrm{h}^{-1}\end{array}$} \\
\hline & & pancreatic juice & bile & \\
\hline $\mathrm{P}$ & 199 & 16.2 & 55.9 & 1454 \\
\hline K & 184 & 17.3 & 100.2 & 1182 \\
\hline $\mathrm{R}$ & 101 & 20.2 & 43.9 & 1451 \\
\hline $\mathrm{L}$ & 66 & 34.8 & 113.3 & 709 \\
\hline $\mathrm{H}$ & 44 & 11.7 & 72.6 & 1083 \\
\hline $\mathrm{E}$ & 37 & 14.3 & 68.3 & 896 \\
\hline $\mathrm{F}$ & 31 & 19.5 & 26.5 & 1543 \\
\hline $\mathrm{C}$ & 31 & 16.3 & 80.5 & 1715 \\
\hline D & 31 & 21.9 & 95.0 & 1634 \\
\hline B & 22 & 14.9 & 67.6 & 825 \\
\hline G & 22 & 15.2 & 71.5 & 962 \\
\hline $\mathrm{T}$ & 17 & 19.9 & 51.7 & 1403 \\
\hline \multicolumn{2}{|c|}{ Mean } & 18.5 & 73.7 & 1272 \\
\hline \multicolumn{2}{|c|}{ SEM } & 0.36 & 1.37 & 38.3 \\
\hline
\end{tabular}

Presented data show a statistical decline $\left(0.022 \mathrm{ml} \cdot\right.$ day $\left.^{-1}\right)$ in volume of pancreatic juice secretion $\left(\mathrm{Y}_{1} \mathrm{ml} \cdot \mathrm{h}^{-1}\right)$ as a function of time after the surgery (X - days):

$$
\mathrm{Y}_{1}=21.5-0.022 \mathrm{X} \quad(\mathrm{r}=0.208, \mathrm{P} \leq 0.01)
$$

The protein output in pancreatic juice $\left(\mathrm{Y}_{2} \mathrm{mg} \cdot \mathrm{ml}^{-1}\right)$ increased along with time of animals handling (X - days): 


$$
\mathrm{Y}_{2}=60.2+0.098 \mathrm{X} \quad(\mathrm{r}=0.219, \mathrm{P} \leq 0.01)
$$

The correlation coefficient of regression equations is significantly important, however the relationships explain only about $40 \%$ of the observations.

One $\mathrm{ml} \cdot \mathrm{h}^{-1}(\mathrm{X})$ increase in pancreatic juice secretion was correlated with $1.36 \mathrm{ml} \cdot \mathrm{h}^{-1}$ increase of bile secretion $\left(\mathrm{Y}_{3}\right)$ :

$$
\mathrm{Y}_{3}=48.5+1.36 \mathrm{X} \quad(\mathrm{r}=0.32, \mathrm{P} \leq 0.01)
$$

and $15 \mathrm{mg} \cdot \mathrm{h}^{-1}$ of protein output $\left(\mathrm{Y}_{4}\right)$ :

$$
\mathrm{Y}_{4}=994+14.99 \mathrm{X} \quad(\mathrm{r}=0.185, \mathrm{P} \leq 0.01)
$$

Also, protein output $\left(\mathrm{Y}_{5}\right)$ increased of about $15 \mathrm{mg} \cdot \mathrm{h}^{-1}$

$$
\mathrm{Y}_{5}=994+14.99 \mathrm{X} \quad(\mathrm{r}=0.185, \mathrm{P} \leq 0.01)
$$

The modification of Kato and Young method used in the present study is simple and reliable method for pancreatic juice and bile collecting in sheep. It is based on the original technique proposed by Routley et al. (1952) in dogs with chronic implantation of pancreatic catheter in the pancreatic duct and reintroducing pancreatic secretion via a stomach catheter. The advantage of this method is that gallbladder motility is not affected by direct catheter implantation or other intervention.

The method was improved by Butler et al. (1960) who placed catheter into duodenum instead of stomach to preserve activity of pancreatic enzymes. Other surgical methods in small ruminants, except common bile duct catheterization for pancreatic juice, introduce different approach to collect bile: direct catheter's implantation to the gallbladder (Pierzynowski, 1983) or gallbladder anastomosis directly to the duodenum (Magee, 1961).

Also, the way of reintroducing secretion back into duodenum could be different: T- shaped cannula (Šileikienè et al., 2004), duodenal catheter (Kato et al., 1984), catheter in the common bile duct towards the duodenal papilla (Naranjo et al., 1986) or Thomas type (two flanged cylinder) cannula (Magee, 1961).

The importance of presented method is the innovated valve of duodenal cannula (Figure 1) which prevents the secretion and intestinal fluid and return pancreatic juice and bile backflows that occur in Routley's method with T-shaped cannula (Zabielski et al., 1997). Our method not only prevents the back flow of digesta to the pancreatic or/and bile duct, but also is less labour and more to experimental animals than methods used by other authors.

Secretion of pancreatic juice and bile in sheep may depend on many conditions such as: animal breed and BW, technique used for cannulation (Kato et al., 1999), nutrition and diets composition (Harada and Kato, 1983; Kato et al., 1984; Harmon, 1992; Kowalik et al., 2001; Żebrowska et al., 2001; Šileikienė et al., 2004). 
Some authors have reported the following output of pancreatic juice: $7.8 \mathrm{ml} \cdot \mathrm{h}^{-1}$ (Kato et al., 1984), $13-30 \mathrm{ml} \cdot \mathrm{h}^{-1}$ (Pierzynowski, 1983), $12.4 \mathrm{ml} \cdot \mathrm{h}^{-1}$ (Magee, 1961), $20.4 \mathrm{ml} \cdot \mathrm{h}^{-1}$ (Korczyński et al., 2004). The extrapolated volume of pancreatic juice and bile in our experiment $\left(46-148 \mathrm{ml} \cdot \mathrm{h}^{-1}\right)$ was lower as that reported by Kowalik et al. (2001) - 83-174 $\mathrm{ml} \cdot \mathrm{h}^{-1}$ and higher as reported by Żebrowska et al. (2001) - 48-58 $\mathrm{ml} \cdot \mathrm{h}^{-1}$ and Johnson et al. (1974) - $69.5 \mathrm{ml} \cdot \mathrm{h}^{-1}$.

In the study of Żebrowska et al. (2001), 35\% increase of crude protein in DM of the diet led to significant rise in volume of pancreatic-biliary secretion (58.3 vs $\left.48.3 \mathrm{ml} \cdot \mathrm{h}^{-1} ; \mathrm{P} \leq 0.01\right)$. However, in the presented study pancreatic-bile juice secretion was at the similar level regardless of protein source: $89.8 \mathrm{vs} 94.6 \mathrm{ml} \cdot \mathrm{h}^{-1}$ for casein and zein, respectively.

It is difficult to compare the data with other authors, because of different animals breed as well as experimental conditions and surgery.

Less successful animals handling (17-40 days) were related to obstructed flow of pancreatic juice, however these animals remained healthy for more than 2 weeks, which suggests the bypass of the secretion of pancreatic juice or/and bile directly to the duodenum or persistence of the second duct.

The necropsies of liver and pancreas showed no lesions. The enlargements of common bile ducts close to catheters insertions were found. It is normal physiological adaptation to changed pressure and modified flow inside the duct. Similar changes occur after implantation of indwelling catheters.

\section{CONCLUSIONS}

Modification of Kato and Young method allows extending the period of animals use even up to more than 6 months. Moreover, it positively impacts animals welfare by reducing time spending in the metabolic cages, and saves labour expenses.

\section{REFERENCES}

Butler H.C., Brinkman D.C., Klavano P.A., 1960. Cannulation of the bovine pancreatic duct. Amer. J. Vet. Res. 21, 205-211

Harada E., Kato S., 1983. Effect of short-chain fatty acids on the secretory response of the ovine exocrine pancreas. Amer. J. Physiol. - Gastrointest. L. 244, G284-G290

Harmon D.L., 1992. Impact of nutrition on pancreatic exocrine and endocrine secretion in ruminants: a review. J. Anim. Sci. 70, $1290-1301$

Johnson T.O., Mitchell Jr. G.E., Tucker R.E., Schelling G.T., 1974. Pancreatic lipase secretion by sheep. J. Anim. Sci. 39, 947-951

Kato S., Onaga T., Zabielski R., Leśniewska V., Guilloteau P., 1999. Characteristics of in vivo and in vitro experimental models. In: Biology of the Pancreas in Growing Animals. S.G. Pierzynowski, R. Zabielski (Editors). Elsevier, pp. 89-122 
Kato S., Usami M., Ushijima J., 1984. The effect of feeding on pancreatic exocrine secretion in sheep. Jpn. J. Zoot. Sci. 55, 973-977

Korczyński W., Kirat D., Kato S., 2004. Exogenous leptin does not affect exocrine pancreatic secretion in conscious sheep. J. Anim. Feed Sci. 13, Suppl. 1, 425-428

Kowalik B., Kowalczyk J., Pająk J.J., Żebrowska T., Długołęcka Z., 2001. The influence of dietary starch level and type on the activity of pancreatic digestive enzymes in sheep. J. Anim. Feed Sci. 10, Suppl. 2, 57-63

Magee D.F., 1961. Investigation into the external secretion of the pancreas in sheep. J. Physiol. 158, 132-143

Naranjo J.A., Valverde A., Martinez de Victoria E., Mañas M., Moreno M., 1986. Surgical preparation for the study of pancreatic exocrine secretion in the conscious preruminant goat. Lab. Animals 20, 231-233

Pierzynowski S.G., 1983. A method of collecting pancreatic juice and bile in conscious sheep. Ann. Warsaw Agr. Univ., SGGW-AR, Vet. Med. 11, 65-67

Routley E.F., Mann F.C., Bollmann J.L., Grindlay J.H., 1952. Effects of vagotomy on pancreatic secretion in dogs with chronic pancreatic fistula. Surg. Gynec. Obstet. 95, 529-536

Šileikienė V., Mosenthin R., Kruszewska D., Krasicka B., Pierzynowski S.G., 2004. Effect of intraruminally and intraduodenally infused short-chain fatty acids (SCFA) on pancreatic juice outflow in sheep. Vet. Zoot. (Lithuanian) 25, 90-93

Zabielski R., Leśniewska V., Guilloteau P., 1997. Collection of pancreatic juice in experimental animals: mini-review of materials and methods. Reprod. Nutr. Develop. 37, 385-399

Żebrowska T., Kowalczyk J., Pająk J.J., Długołęcka Z., 2001. The influence of dietary protein and fibre on bile-pancreatic secretion in sheep. J. Anim. Feed Sci. 10, 619-626 